\title{
IMPLEMENTATION OF PROBLEM BASED LEARNING MODEL WITH NEWSPAPER MEDIA TO IMPROVE STUDENTS CRITICAL THINKING IN SOCIAL SCIENCE LEARNING VIII-A GRADE

\author{
(Classroom Action Research in SMP Pasundan 6 Bandung)
}

Kanirawati*, Dadang Sundawa, Kokom Komalasari

Social Studies Education Department

kanirawati473@gmail.com

\begin{abstract}
Abstrak--Penelitian ini dilatar belakangi oleh rendahnya kemampuan berpikir kritis siswa dalam kelompok pada pembelajaran IPS di kelas VIII A SMP Pasundan 6 Bandung. Tujuan dari penelitian ini yaitu untuk menggambarkan perencanaan, pelaksanaan, hasil, kendala dan upaya dalam penerapan model pembelajaran berbasis masalah dengan media koran untuk meningkatkan kemampuan berpikir kritis siswa. Penelitian ini menggunakan PTK dengan model Kemmis dan Taggart dengan menggunakan pembelajaran berbasis masalah. Subjek dari penelitian ini adalah siswa kelas VIII A SMP Pasundan 6 Bandung sebanyak 36 siswa. Beberapa perencanaan dari penelitian ini diantaranya menyusun RPP dan membuat instrumen penelitian sesuai kebutuhan peneliti.Penelitian ini dilaksanakan selama tiga siklus dan diperoleh hasil peningkatan kemampuan berpikir kritis siswa dalam pembelajaran IPS. Pada pelaksanaan siklus tersebut terjadi peningkatan yaitu dari siklus satu kemampuan berpikir kritis siswa diperoleh dengan kriteria cukup, pada siklus kedua dengan kriteria cukup dan siklus tiga dengan kriteria baik. Peningkatan tersebut salah satunya ditandai dalam kegiatan diskusi kelompok, diantaranya banyak siswa yang bertanya, mampu menjawab pertanyaan yang diajukan oleh guru dengan menggunakan bahasa sendiri dan kalimat yang mudah dipahami dan mampu menemukan dan memecahkan permasalahan yang ada di lingkunganyya yang berkaitan dengan materi IPS. Kendala dari penelitian ini salah satunya adalah sulitnya mencari koran yang berkaitan dengan materi yang disampaikan dan pelaksanaan pembelajaran yang kurang sesuai dengan RPP. Kendala tersebut dapat diatasi dengan beberapa solusi diantaranya dengan memperbanyak membaca koran dari berbagai sumber sebelum melaksanakan tindakan dan memperbaiki proses pembelajaran dengan menyampaikan materi sesuai dengan RPP yang telah di susun. Penelitian ini menggunakan analisis data kualitatif dan kuantitatif.
\end{abstract}

Kata kunci : Model pembelajaran berbasis masalah, Kemampuan berpikir kritis

Abstract--This research was motivated by the low ability of student's critical thinking in a group of Social Science learning in VIII-A Grade SMP Pasundan 6 Bandung. The purpose of this research is to describe planning, implementation, result, obstacle and effort in the implementation of problem-based learning model with newspaper media to improve student's critical thinking ability. This research uses classroom action research with Kemmis and Taggart model by using problem-based learning and newspaper as learning media. The subjects of this research are37 students of VIII-A Grade SMP Pasundan 6 Bandung. Planning of this research includes preparing RPP(Instruction Plan) and making instrument according to the needs. This research was conducted for three cycles and obtained the result of student's critical thinking improvement in Social Science learning from first cycle until third cycle. The student's critical thinking ability in the first with the enough category, in the second with the enough category and in the third cycle with the good category. The increase is signed by the number of students who ask questions, answer questions asked by teachers by using their own language and using sentences that are understandable, as well ascan find and solve existing problems in the environment related to the subject in a group discussion activity. The problem of this research are the difficulty of finding newspapers related to the subject presented and the implementation of lesson is inappropriate with the instruction plan. These obstacles can be solved by reading of newspapers from various sources before implementing the action and improving the learning process by delivering the subject in accordance to the instruction plan that has been compiled. This research uses qualitative and quantitative data analysis.

Keywords: Problem-based learning model, Critical thinking ability 


\section{INTRODUCTION}

This research is based on the problems that researchers found during the pre-research observation in class VIII A SMP Pasundan 6 Bandung in IPS learning. Based on these observations, there are some problems that researchers find among them. Most of the students are not able to answer questions asked by teachers about the material which is quite easy and related to the IPS material that is being conveyed. Another problem is that students do not know how to solve problems related to the IPS material delivered by the teacher. In addition some students can answer but are not able to use the language and sentences understood by their friends. Based on these findings, researcher assumes that the problem is related to the ability to think critically. The proof is that students are not able to answer questions posed by the teachers. It is related to the ability of high-level thinking or often called critical thinking of students. The students have not been able to identify and think more specific to the material being conveyed by the teacher and their answer is less logical. So it can be said that students' critical thinking skills in class VIII $\mathrm{A}$ is low and it should take an action to correct the problem. The ability of critical thinking is needed by everyone, especially students who will become the forerunner of the nation's successor. The ability of thinking can be developed one of them through the process of learning in the classroom. According to Komalasari (2014, pp. 3 ), learning can be defined as a system or process of teaching students that are planned and evaluated systematically so that students can achieve learning goals. Therefore, teachers should be able to provide learning with a more planned to achieve results that increase students' critical thinking skills. According to the theory of Gagne that Purwonto discloses (in Mustofa and Thobroni, 2011. pp. 20) "Learning occurs when the stimulus situation along with the contents of memory affect students so that his actions change from time to time after he experienced the situation to the time after he experienced the situation earlier". Therefore, learning activities will occur if teachers provide stimulus to students one of them by providing questions or problems before learning then students will think more active or so-called critical thinking. Critical thinking is the activity of analyzing ideas or ideas in a more specific way, distinguishing sharply, choosing, identifying, examining and developing them in a more perfect direction. (Dwijananti and Yulianti, 2010, p. 112). According to Wahab (2009) "Thinking critical or reflective is a process of rearranging and organizing information and knowledge to produce a new knowledge". Therefore, critical thinking becomes very important and must be developed because students will be required to think more specifically and must be able to choose and identify a problem that will be found later in life. Critical thinking ability is needed in the learning process, especially in IPS learning. This is related to the purpose and understanding of the IPS itself. According to James A. Banks (in Sapriya, 2008. pp. 3) "Social Studies is part of the primary and secondary school curriculum that has the primary responsibility of helping students to develop knowledge, skills, attitudes and values needed in the life of the state in the community". Based on this understanding, IPS becomes an important subject to develop cognitive, affective and even student skills especially in social life. In the lesson IPS mentioned that the ability to think is preferred, it is supported with the aim of the IPS subject. According to Sapriya (2009, pp. 201), the objectives of Social Studies subjects as follows: A. Know the concepts related to the life of society and its environment. B. Have basic skills for logical and critical thinking, curiosity, inquiry, problem solving, and skills in social life.

C. Have commitment and awareness to social values and humanity.

D. Have the ability to communicate, work together, and compete in a plural society, locally, nationally and globally.

Based on the exposure, one of the objectives of social studies subjects is to have basic skills for logical thinking, critical, curiosity, inquiry, problem solving, and skills in social life. Thus, students' critical thinking skills in IPS learning take precedence and become basic skills. In solving a problem, students must think first to find a variety of solutions to problem solving. It is called the ability to think critically. Method option or learning model used to be a determining factor in achieving the success of learning goals. In education, there are many learning models that teachers can use in accordance to the ability of teachers and the needs of students. Learning methods and models will make it easier for teachers to deliver materials and make 
classroom more lively and meaningful. Likewise with the problems that researchers find, to improve the ability of critical thinking students choose a learning model that can stimulate students' critical thinking skills. Problem-based learning model or often called Problem Based Introduction is a learning model based on the principle of using the problem as the starting point of acquisition and integration of new knowledge according to Al-Tabany (2013, pp. 63). Based on that understanding, problem-based learning will be able to stimulate students 'critical thinking ability to social problems especially in IPS learning because teachers use problems to stimulate students' critical thinking ability. According to Al-Thabany (2013, p.68) there are several benefits of problem-based learning: a) Helping students to develop thinking and problem-solving skills, b) Learning the role of authentic adults, and c) Being an independent learner. The first point explains that the purpose of problem-based learning is to develop the thinking skills that are related to students' critical thinking skills in IPS learning. It is also supported by the opinion of Nurhadi et al (in Baharuddin, pp. 116) students need to be accustomed to solve problem, find something useful for them and wrestle with new ideas. Thus the researcher uses problem-based learning model to improve critical thinking skills of class VIII A students in IPS learning. The critical thinking indicators used by researchers are as follows.

\section{Table 1 Critical Thinking Indicators According to Research Needs}

\begin{tabular}{|l|l|ll|}
\hline Group & Indicator & Subindicator \\
simple & Focus on & $\bullet$ & Identify or \\
explanation & question & formulate \\
& & question \\
& & Identify or \\
& & formulate \\
& & criteria to \\
& & consider \\
& & & possible \\
& & answer \\
\hline & Analyze & Identify \\
& argument & & conclusion \\
\hline
\end{tabular}

\begin{tabular}{|l|l|cl|}
\hline & $\begin{array}{l}\text { Ask and } \\
\text { answer } \\
\text { question }\end{array}$ & $\bullet$ & Give example \\
\hline $\begin{array}{l}\text { Build basic } \\
\text { skill }\end{array}$ & & $\bullet$ & Ability to give \\
Give & explanation \\
further & and definition & & argument \\
argument & & & definition in a \\
& & sentence \\
\hline
\end{tabular}

Source: Ennis (in Anisa, 2015, p.27)

To make it easier in applying problem-based learning model, it is better for teachers to use instructional media that will support and simplify the learning process. In this study, researchers use the newspaper as a medium of learning in using problem-based learning models to improve students' critical thinking skills. In this study, researchers explain the newspaper and use the news column as a source of information derived from the newspaper compass and people's minds. According to Yunus (in Handani, 2015, p.23) explains that newspaper is a communication media containing actual information from various aspects of life such as politic, economic, crime, art, sport and so on. Based on this understanding, the newspaper is very suitable for applying problem based learning in improving students' critical thinking skills because the newspaper contains various information about politics, economy, crime and so on, such thing is very closely related to IPS learning.

Based on the problems above, the researcher made some formulation of research problem such as: First, design planning application of problem-based learning model with newspaper media to improve students' critical thinking skill in IPS learning class VIII A in SMP Pasundan 6 Bandung. Second, the implementation of problem-based learning model with newspaper media to improve students' critical thinking skills in IPS learning class VIII A in SMP Pasundan 6 Bandung. Third, improving students' critical thinking ability after using problem based learning with newspaper media in IPS learning class VIII A in SMP Pasundan 6 Bandung. Fourth, how are the obstacles that arise and how to overcome the obstacles that arise in the application of problem-based learning model with newspaper media to 
improve students' critical thinking skills in learning IPS class VIII A in SMP Pasundan 6 Bandung.

\section{RESEARCH METHOD}

The method used in this research is Classroom Action Research method (PTK). As stated by Kemmis (1988 in Sanjaya 2009, p.24) "action research is a form of reflective and collective research conducted by researchers in social situations to improve the reasoning of their social practice". According to Sanjaya (2009, p.24) suggests that "the main feature of action research is the existence of certain interventions or treatment for performance improvement in the real world". Thus Classroom Action Research is a research method based on actions to improve performance, in this term the quality of learning in the classroom. This research uses PTK model from Kemmis and Mc Taggart which consists of four components, namely: plan, action, observation and reflection. The subjects of this study are students of class VIII A SMP Pasundan 6 Bandung consisting of 11 male students and 26 female students with the number of students as much as 37 . Selection of this class based on the consideration of researchers from the observations at the time of IPS learning that turns critical thinking skills students in that class are still said to be low and need an increase. The Kemmis and Taggart models are described as follows.

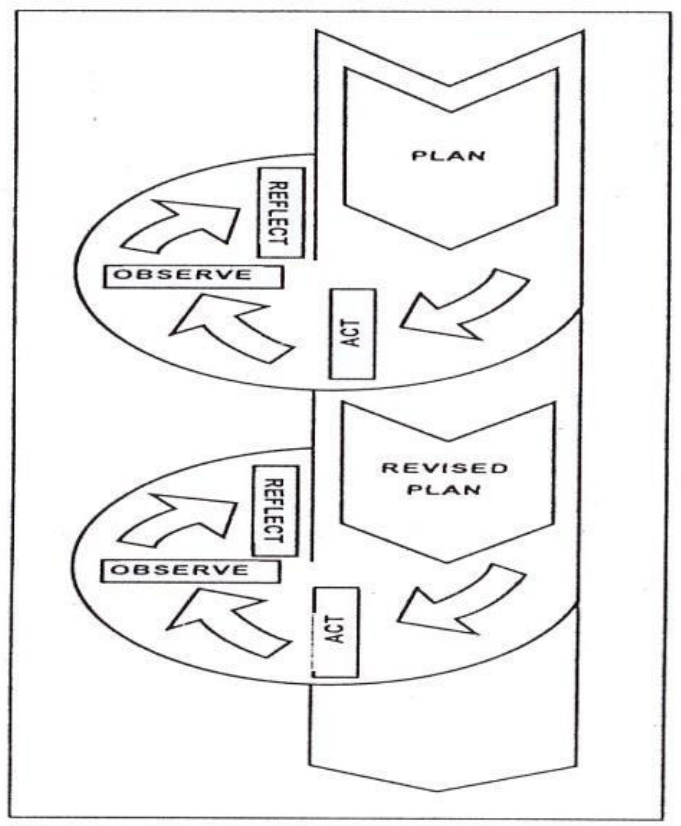

Figure 1 Model of PTK Kemmis and Mc Taggart
(Source: Wiraatmadja, 2012,

p.66)

Researcher who act as a teacher collaborate with a guide teacher and colleagues who became observer. Besides become observer, they also become a discussion partner researcher in doing data processing and reflecting the results of each action done. Data collection technique is conducted by observations, interviews, and documents related to classroom action research such as field notes, RPP (instruction plan), etc., as well as photographs during carrying out the learning activities. The observation instruments used are the observation sheet of critical thinking skills of students, teacher activity observation sheets in learning and activity sheets of teachers in implementing problembased learning.

\section{RESULTS AND DISCUSSION}

This study was conducted in three cycles. Each cycle consists of two actions. To be more detailed, the results and discussion of each cycle are as follows: Cycle 1, at the planning stage, teacher determines the time that is on Wednesday, March 15, 2017, then the teacher determines the material according to the standard of competence (SK) 7. Understand the activities of the Indonesian economy and basic competence (KD) 7.1. Describe the problems of the labor force, labor and employment as a resource in economic activity, and the role of government in the effort to overcome it. Based on the SK and KD, the researchers take the main material in implementing the action of employment (understanding of labor, labor force and employment). In addition, teachers prepare newspapers containing news about labor, organize instruments and observation sheets, prepare tools such as resource books, laptops and so on, and divide students into 6 small groups. In the implementation stage, the teacher divides the learning process into three activities namely the beginning activities, core activities and closing activities. In the early activity the teacher opened the lesson by greeting, praying, checking the class neatness and absorbing. In the core activities, teachers do a little apperception. After displaying images in the form of labor problems that exist in Indonesia, then the teacher asks the students, "What do you know about this picture?" The student replied "long queue, Maam.", Why is long queue? "Looking for work, Maam." Then 
what is the labor?". (No students answered). About 30 minutes the teacher explained about employment and pictures of people looking for work. After explaining then the teacher asks the students to work in a group in analyzing the newspaper about the employment. Each group received different newspapers with different types of labor as well. After finishing the group discussion, the teacher invites each group to present the results of the group discussion. In closing activities, the teacher gives conclusions and reinforces the material on employment.

In the reflection phase, the researcher performs data processing and discussion with observer that is a guide teacher and colleagues. Based on the result of first cycle implementation, the data is calculated and accumulated from the group assessment into the grade assessment so that the data are as follows. Table 2 Acquisition of Student's Summary Value on Cycle 1 Action in Critical Thinking

\begin{tabular}{|c|c|c|}
\hline No & No Group & $\begin{array}{c}\text { Score } \\
\text { Acquisition } \\
\text { Cycle 1 }\end{array}$ \\
\hline 1 & 1 (One) & 17 \\
\hline 2 & 2 (Two) & 15 \\
\hline 3 & 3 (Three) & 15 \\
\hline 4 & 4 (Four) & 16 \\
\hline 5 & 5 (Five) & 12 \\
\hline 6 & 6 (Six) & 16 \\
\hline \multicolumn{2}{|c|}{ Total of Score } & 91 \\
\hline \multicolumn{2}{|c|}{ Maximal Score } & 216 \\
\hline \multicolumn{2}{|c|}{ Percentage } & $42 \%$ \\
\hline \multicolumn{2}{|c|}{ Criteria } & Enough \\
\hline
\end{tabular}

The obstacles that researcher finds in the implementation of the first cycle is the teacher seemed hasty in delivering material. It is due to lack of ability to allocate time and not in accordance with RPP (instruction plan) so the students' critical thinking skills still need to be improved because there are still many indicators that have not achieved and obtained scores with 'enough' criteria. It is not because of the students only but the teacher factor is also very important so that teachers must make improvements in the next cycle. Cycle 2, at the planning stage determines the time of action on Monday, March 27, 2017 and Wednesday, March 29, 2017. In the implementation of the second cycle carried out two actions. It is based on reflection from the implementation of the first cycle. Other planning is to determine the material based on competency standards (SK) 7. Understanding the Indonesian economic activities and basic competence (KD) 7.1. Describe the problems of the labor force, labor and employment as a resource in economic activity, as well as the role of government in its efforts to overcome it with the subject matter of labor issues. In addition teachers prepare RPP (instruction plan) and develop the instruments that will be used.

In the first stage, the teacher divides learning activities into three parts: the beginning, core and closing activities. In the first action the teacher focuses on the delivery of material about labor problems. Before discussing the material, teachers stimulate critical thinking skills students by asking questions and displaying images. "Students, try to see why there is a crime, poverty and hunger? What does it have to do with labor?". (Some students answered). "Because they do not have jobs, because the uneven field of employment". About 30 minutes the teacher delivered material on labor issues. In the second act the teacher focuses on group discussion activities. Teachers discuss learning activities with three activities: beginning, core and closing. In the core activities, the teacher divides the students into 6 small groups and divides the newspaper to each group. The newspaper analyzed during the discussion in the second cycle is about the effects of labor problems. Teachers give students about 30 minutes to conduct group discussions. After finishing the discussion, the teacher asks the group to present the discussion result. In the discussion activity, the teacher encourages the students to actively ask and answer. Some students are not shy anymore in asking questions and answer it. In the reflection phase, teachers process data and conduct discussions with observers. The acquisition score of students' critical thinking skills in the second cycle is as follows.

Table 3 Acquisition of Student's Summary Value in Cycle Action 2 In Critical Thinking

\begin{tabular}{|c|l|c|}
\hline \multicolumn{1}{|c|}{ Group } & $\begin{array}{c}\text { Score } \\
\text { Acquisition } \\
\text { Cycle 2 }\end{array}$ \\
\hline 1 & 1 (One) & 24 \\
\hline 2 & 2 (Two) & 22 \\
\hline 3 & 3 (Three) & 23 \\
\hline 4 & 4 (Four) & 23 \\
\hline
\end{tabular}




\begin{tabular}{|c|c|c|}
\hline 5 & 5 (Five) & 24 \\
\hline 6 & 6 (Six) & 23 \\
\hline \multicolumn{2}{|c|}{ Score Total } & 139 \\
\hline \multicolumn{2}{|c|}{ Maximal Score } & 216 \\
\hline \multicolumn{2}{|c|}{ Percentage } & $64 \%$ \\
\hline Criteria & Enough \\
\hline
\end{tabular}

The obstacles in the implementation of the second cycle is less able to set up the class and not preparing the lesson, so it is time wasting at the time of learning because the class condition is not ready but the students' critical thinking skills increased from the first cycle although still in enough criteria. Cycle 3, at the planning stage, the researcher determines the time of action on Monday, April 17, 2017 and on Thursday, April 27, 2017. In addition, the researchers prepare the instrument, develop the RPP (instruction plan) and determine the material according to the standard of competence (SK) 7. Understand the activities of the Indonesian economy and basic competence (KD) 7.2 Describe economic actors: households, communities, enterprises, cooperatives and countries. Based on the SK and $\mathrm{KD}$, the researchers take the main material in implementing the action of understanding the economic system, the various economic systems, and the forms of economic actors in Indonesia. Just as the previous cycle in the implementation of the first act the teacher divides the learning activities into three parts, namely the beginning, core and closing activities. In the first action the teacher focuses in delivering the material about economic actors/business entities in Indonesia. Besides, in the core activities teachers stimulates students and asks about the picture (PT Freeport) and (BUMS). "Students, based on the picture, what is the difference between PT. Freeport and BUMS?" (Some students replied) "It's different. BUMS is private owned and Freeport is state property". Approximately 30 minutes the teacher explains the material about the economic actors/business entities. In the second act, teachers carry out learning activities with the beginning, core and closing activities. In the beginning activities, teachers open the lesson by praying and providing apperception about the material of economic actors/business entities. In the core activities, teachers focus on group discussion activities. Each group is asked to analyze the newspaper about the business entity contained in the newspaper. After discussing the group, the teacher asks the students to present their group discussion result. In the discussion activity, the students have been seen actively and able to refute the opinion of their friend. In the discussion activities there was also a debate between the groups, but the teacher gives the reinforcement, answers and tries to straighten the answers of students who became the debate. The students' critical thinking skills in the group discussions are visible and the students are so enthusiastic to ask questions of the newspaper analyzed by the other groups. In closing activities, the teacher asks the students to give conclusions about the business entity material as well as provide reinforcement about the material of economic actors. Then, the teacher closes the lesson and prays together. The score obtained from the implementation of the third cycle is as follows:

Table 4 Acquisition of Student's Summary Value in Cycle Action 3 in Critical Thinking

\begin{tabular}{|c|l|c|}
\hline No & \multicolumn{1}{|c|}{ Group } & $\begin{array}{c}\text { Score } \\
\text { Acquisition } \\
\text { Cycle 3 }\end{array}$ \\
\hline 1 & 1 (One) & 34 \\
\hline 2 & 2 (Two) & 35 \\
\hline 3 & 3 (Three) & 32 \\
\hline 4 & 4 (Four) & 32 \\
\hline 5 & 5 (Five) & 32 \\
\hline 6 & 6 (Six) & 33 \\
\hline \multicolumn{2}{|c|}{ Score Total } & 198 \\
\hline \multicolumn{2}{|c|}{ Paximal Score } & 216 \\
\hline \multicolumn{2}{|c|}{ Criteria } & $93 \%$ \\
\hline \multicolumn{2}{|c|}{ Good } \\
\hline
\end{tabular}

The obstacles in carrying out the third cycle are not too much, but teachers should be able to set up the class during group discussion activities. The obstacles that researcher finds in each cycle is in newspapers that related to material to be delivered. However, these obstacles can be overcame by increasing the gathering of newspapers and choosing news that is appropriate to be analyzed by junior high school students.

\section{CONCLUSION}

The results of classroom action research entitled Implementation of Problem Based Learning Model with Newspaper Media to Improve Students Critical Thinking in Social Science Learning VIII-A Grade can be summarized as follows. First, action planning that needs to be considered is the preparation of the RPP in 
accordance with the standards of competence and core competence. In addition, the planning that needs to be considered is in the application of problem-based learning by using newspaper to improve students' critical thinking in this study is conducted by: a) determining the contextual theme, b) planning the steps of learning activities, c) looking for problems from the appropriate newspaper, d) making an assessment. Secondly, the implementation of classroom action research is carried out with three cycles. Each cycle consists of two actions. Only in the first cycle consists of one action, but after reflection the next cycle consists of two actions. Material which is delivered at each cycle is different. In the learning activities, the teacher divides the three core activities of the beginning, core and closing activities. In the first action the teacher focuses on the delivery of the material while in the second act the teacher focuses on group discussion activities. The implementation of each action is well implemented and in accordance with the RPP that has been compiled. Third, students' critical thinking skills of each cycle have increased. In the first cycle obtained the ability to think critically as many as 42 students with enough criteria, as well as the second cycle gets a score of 64 with enough criteria. In the third cycle has very significant increase and obtained the ability to think critically students score 93 with good criteria. Fourth, the obstacles faced from each cycle are not too much and can be overcome. The problem experienced by each cycle is the difficulty of researchers in connecting materials with newspapers that will be analyzed by students. But it can also be overcome by the hard-work of researchers looking for newspapers and selecting news that match the material and in accordance with the study materials for junior high school students.

\section{REFERENCES}

\section{Book Sources :}

Al-Thabany.(2014).

Mendesain

Model

PembelajaranInovatif,

Progresif,

dan

Kontekstual.Jakarta : PT Kharisma Putra Utama.

Baharuddin \& Wahyuni.(2008). Teori Belajar dan Pembelajaran.Jogjakarta :Ar-Ruzz Media.

Komalasari, K. (2011), Media Pembelajaran IPS.Bandung : Universitas Pendidikan Indonesia.

Mustofa, A. \& Thobroni M. (2011).Belajar danPembelajaran : Pengembangan Wacana dan
Praktik Pembelajaran dalam Pembangunan

Nasional. Jogjakarta : Ar-Ruzz Media.

Sanjaya, Wina. (2009).

Penelitian

TindakanKelas.Jakarta : Kencana.

Sapriya.(2012). Pendidikan IPS.Bandung : CV Yasindo

Multi Aspek.

Sapriya.(2008). Konsep Dasar IPS.Bandung :CVYasindo Multi Aspek.

Wiraatmadja, R. (2010). Metode Penelitian Tindakan Kelas..Bandung : PT Remaja Rosda Karya.

M.A. Nasution. (2009). Berbagai Pendekatan dalam Proses Belajar dan Mengajar.Jakarta : PT Bumi Aksara.

Wahab, A.A. (2009). Metode dan Model-Model Mengajar Ilmu Pengetahuan Sosial (IPS).Jakarta : Alfabeta.

\section{Thesis Sources:}

Handani, Ivan (2015) Koran sebagai Sumber Belajar IPS untuk Meningkatkan Keterampilan Siswa dalam memecahkan Masalah melalui Strategi Pembelajaran Berbasis Masalah pada Siswa kelas VIII K SMPN 4 Cimahi.(Skripsi) Universitas Pendidikan Indonesia : Bandung.

\section{Journal Sources :}

Dwijananti \& Yulianti. (2010). Pengembangan Kemampuan Berpikir Kritis Mahasiswa Melalui Pembelajaran Problem Based Instruction Pada Mata Kuliah Fisika Lingkungan. Jurnal Pendidikan Fisika Indonesia. (6), hlm. 108-114. 